\title{
Taxonomy and conservation of Philippine Cycads
}

\author{
D.A. Madulid ${ }^{1}$, E.M.G. Agoo
}

\section{Key words}

cycad conservation

cycad taxonomy

Philippine threatened plants

\begin{abstract}
Six species of cycads are recorded in the Philippines, three of which are endemic. The different species of cycads can be recognized by the characters of the microsporophylls, megasporophylls, and seeds. The current conservation status of the different species of Cycas is assessed and categorized using the IUCN criteria on basis of currently available information.
\end{abstract}

Published on 30 October 2009

\section{REVIEW OF THE TAXONOMY OF PHILIPPINE CYCAS}

There has been considerable confusion and difference in opinion about the recognition of taxa and the classification of species in the genus Cycas.

Merrill (1923) listed 4 species of cycads. He used the name C. rumphii Miq. for the widespread species, C. cairnsiana F.Muell. for a specimen from Culion Island, C. revoluta Thunb. for an introduced species, and retained an unnamed species based on a collection from Palawan.

Brown \& Kienholz (1925) described a new species, C. chamberlainii, from Mt Arayat, Pampanga. This species was later reduced to a synonym of $C$. riuminiana Porte ex Regel by De Laubenfels \& Adema (1998).

Schuster (1932) described C. circinalis subsp. riuminiana var. curranii on basis of a specimen collected by $\mathrm{H}$. Curran on the river banks of Molinao river in Palawan. This was raised to a species, Cycas curranii, by Hill (1995). At the same time, Schuster distinguished $C$. circinalis subsp. riuminiana var. curranii forma graminea based on the specimen from Culion Island that was named C. cairnsiana by Merrill (1923). However, Merrill (1936), studying more collections from the same island, distinguished these as $C$. wadei, on basis of the unique seed characteristics.

In an account of the gymnosperms of the Philippines, Zamora \& Co (1979) recognized 4 species including $C$. wadei and applied the name $C$. circinalis to the widespread $C$. rumphii.

A review of the Cycas of the Philippines based on vegetative and sporophyll characters was made by Amoroso (1986). In this study, he recognized 5 species and distinguished the more common mountain cycads as $C$. circinalis from the coastal cycads which he retained in $C$. rumphii.

According to De Laubenfels \& Adema (1998), neither C. rumphii nor C. circinalis occur in the Philippines. They apply the name C. silvestris K.D.Hill (considered as endemic for Queensland by Hill 1992) to part of the widespread species, and C. edentata de Laub. to the remainder. They recognize $C$. riuminiana Porte ex Regel with a disjunct distribution in the Philippines and Sulawesi, and C. wadei Merr. as a Philippine endemic. Hill separated the specimens of $C$. silvestris from Palawan as

\footnotetext{
Botany Division, National Museum of the Philippines, P. Burgos St., Manila, The Philippines; e-mail: dmadulid@info.com.ph

2 Biology Department, De La Salle University-Manila, 2401 Taft Avenue, Manila, The Philippines; e-mail: agooe@dlsu.edu.ph
}

C. curranii (Hill 1995), the specimens of C. riuminiana from Sulawesi as C. falcata (Hill 1999) and restricts the name C. edentata for specimens from the Philippines (Hill 1998-2004). Cycas riuminiana and $\mathrm{C}$. edentata are thus considered as Philippine endemics by Hill.

One obvious reason for the current variety opinion on the taxonomy of Philippine Cycas is the lack of adequate data about the morphology and biology of the species. Cycad specialists are also limited in their studies as they often base these on herbarium specimens alone and have not seen the actual plants in the field. Variations in the different vegetative characters are overlooked because these are simply not represented in the scanty or limited herbarium specimen. The specimens available for study may be incomplete or young specimens, or may just be either male or female plants. Even with more complete material, some researchers fail to examine the seed characters because this will entail damaging specimens.

It can also be noted that recent explorations of poorly known habitats, i.e. forest over limestone or ultrabasic soils have resulted in new discoveries, e.g. C. saxatilis K.D.Hill \& A.Lindstr. (2008).

The cycads of the Philippines have been evaluated and included in the 2003 IUCN Red List of Threatened Species. Based on the 2001 Criteria (v3.1), C. curranii, C. edentata, C. riuminiana, and C. wadei were all categorized as Data Deficient (DD). Cycas chamberlainii was categorized as Endangered (EN) based on the limits of the extent of occurrence and area of occupancy, severe fragmentation or number of locations and continuing decline in extent of occurrence and number of populations.

Here we present an overview of the Cycads of the Philippines, based on a detailed comparison of the vegetative and sporophyll characters of cycads based on literature, herbarium specimens available at the $\mathrm{PNH}$, recent collections from various localities, as well on-line herbaria digital images. The conservation status of Philippine Cycas species is analyzed and categorized based on land cover maps, derived extent of occurrence and estimated number of populations/subpopulations.

\section{RESULTS}

\section{Taxonomic characters of Philippine Cycas}

Taxonomic characters which are most useful in the identification of the species are the microsporophyll apical spines, megasporophyll shape, and teeth, and seed sarcotesta; size, shape, and presence of ribs. Vegetative character states such as trunk

(c) 2009 Nationaal Herbarium Nederland

You are free to share - to copy, distribute and transmit the work, under the following conditions:

Attribution: $\quad$ You must attribute the work in the manner specified by the author or licensor (but not in any way that suggests that they endorse you or your use of the work).

Non-commercial:

You may not use this work for commercial purpose

No derivative works: You may not alter, transform, or build upon this work.

For any reuse or distribution, you must make clear to others the license terms of this work, which can be found at http://creativecommons.org/licenses/by-nc-nd/3.0/legalcode. Any of the above conditions can be waived if you get permission from the copyright holder. Nothing in this license impairs or restricts the author's moral rights. 

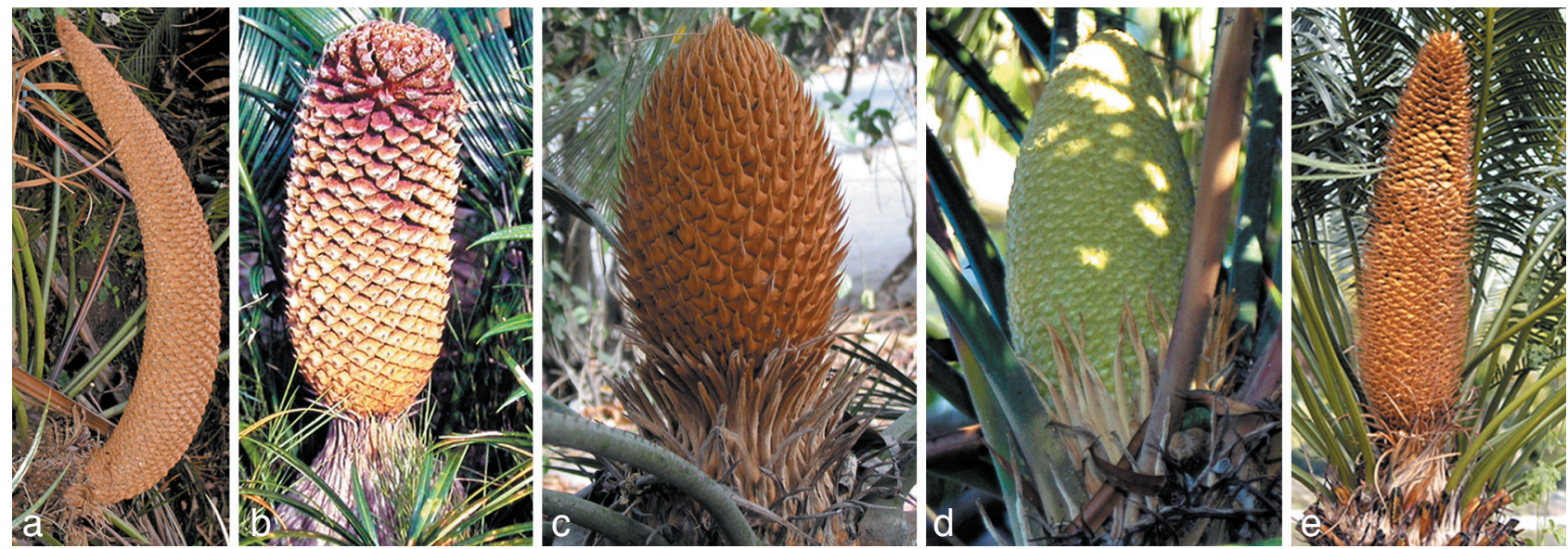

Plate 1 Microsporophylls. a. Cycas curranii (J.Schust.) K.D.Hill; b. C. riuminiana Porte ex Regel; c. C. zambalensis Madulid \& Agoo; d. C. wadei Merr.; e. C. edentata de Laub.

height and diameter, pinnule number per side of rachis, pinnule length and width overlap in many species are of limited value for the identification of species

We distinguish six species in the Philippines: C. curranii, $C$. edentata, C. riuminiana, C. silvestris, C. wadei, and C. zambalensis. Recent discoveries, e.g. C. saxatilis, are not included as neither a description nor a specimen was available when we prepared this account.

\section{KEY TO THE SPECIES OF CYCAS IN THE PHILIPPINES}

1. Apex of megasporophylls entire, shallowly dentate or serrate; lateral teeth up to $6 \mathrm{~mm}$ long . . . . . . . . . . . . 2

1. Apex of megasporophylls pectinate; lateral teeth at least

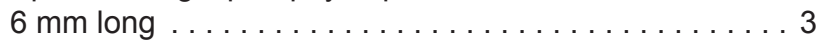

2. Apex of megasporophylls entire; spongy layer in seed present ...................... C. edentata

2. Apex of megasporophylls shallowly dentate or serrate; spongy layer in seed absent . . . . . . . . . C. silvestris

3. Petiole and rachis tomentose ............. 4

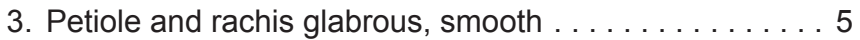

4. Margins of pinnules revolute ... . . . . . . . C. revoluta

4. Margins of pinnules flat ............ . zambalensis

5. Midveins of pinnules prominent on the upper side. Petioles 25-70 (mostly over $40 \mathrm{~cm}$ ) long; seeds not ribbed . . . . .

C. riuminiana

5. Midveins of pinnules flat or slightly prominent at the upper side. Petioles to 40 (mostly less than 30 ) cm long; seeds

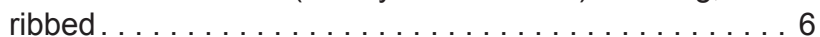

6. Microsporophyll with spine 5-6 mm long; seeds 5-6 ribbed, 33-37 by $28-29 \mathrm{~mm}$. . . . . . . . . . . . . . . . wadei

6. Microsporophyll without spine; seeds at least 10-ribbed, $44-46$ by $36-37 \mathrm{~mm}$. . . . . . . . . . . . . . . . curranii

Cycas curranii (J.Schust.) K.D. Hill - Plate 1a, 2b-e, 3

Cycas curranii (J.Schust.) K.D.Hill (1995) 150.

Cycas circinalis subsp. riuminiana var. curranii J. Schust. (1932) 69.

Cycas cairnsiana auct. non F. Muell.: Merr. (1923) 1

Cycas wadei auct. non Merr.: Zamora \& Co (1979) 222, f. 4

Distribution - Philippines: Palawan, Mindoro (Oriental Mindoro).

Habitat - Lowland forests over ultrabasic soils and open grasslands.

Conservation status - The species is limited to the degraded forests in the eastern part of Mindoro Island and Southern
Palawan. The original forest cover in many parts of Mindoro has been extensively degraded and converted to grassland. The grasslands are seasonally burned to regenerate grass for cattle. Seeds of this species are also collected and used as ornaments. The (maximum) extent of occurrence is (less than) $4100 \mathrm{~km}^{2}$, with only 2 locations, and there is a continuing decline in quality of habitat. Based on these criteria, its category is Critically Endangered.

Descriptive notes - Cycas curranii has microsporophylls with apex not extending to a spine-like structure. The apex is instead abruptly bent and tucked downwards. The seed sarcotesta are longitudinally ribbed similar to $C$. wadei, but the ribs are more pronounced and more in number than in $C$. wadei.

\section{Cycas edentata de Laub. - Plate 1e, 2f, 3}

Cycas edentata de Laub. in de Laub. \& Adema (1998) 373, f. 1 Cycas circinalis auct. non L., Zamora \& Co (1979) 219, f. 1, 2.

Cycas rumphii auct. non Miq.: Amoroso (1986) 182, f. 2, 6, 17-19, 23-26.

Distribution - Andamar Islands to Timor; throughout the Philippines

Habitat - Coastal forests and thickets.

Conservation status - Cycas edentata is a non-endemic widespread coastal species in the Philippines. It usually occurs on beach forest strands and rocky outcrops. There are apparently no current threats to the species or to its habitat. Its category is Not Threatened.

Descriptive notes - This species has megasporophylls with reduced teeth or almost wanting. It is also the only species with a spongy layer in the endocarp.

Cycas riuminiana Porte ex Regel — Plate 1b, 2g, 3

Cycas riuminiana Porte ex Regel (1863) 16, f. on p. 17; de Laub. \& Adema (1998) 382.

Cycas circinalis L. subsp. riuminiana (Porte ex Regel) J.Schust. (1932) 68. Cycas chamberlainii W.H.Br. \& R.Kienholz (1925) 47, f. 1, pl. 1-3; Zamora \& Co (1979) 219; Amoroso (1986) 181-182, f. 4, 14-16, 39-41.

Cycas circinalis subsp. riuminiana var. curranii forma chamberlainii (W.H.Br. \& R.Kienholz) J.Schust. (1932) 69.

Distribution — Philippines: Luzon; Sulawesi; Moluccas. Habitat - Lowland forests.

Conservation status - The species is limited to the lowland mountain forests of Pampanga, Bataan, Batangas, and Isabela in Luzon Island. Though the specific localities are currently in protected areas, their natural habitats are affected by natural and anthropogenic pressures, i.e. landslides, clearing for hiking trails, as well as potential conversion of forests into agricultural plots. The (maximum) extent of occurrence is $9500 \mathrm{~km}^{2}$, with at 

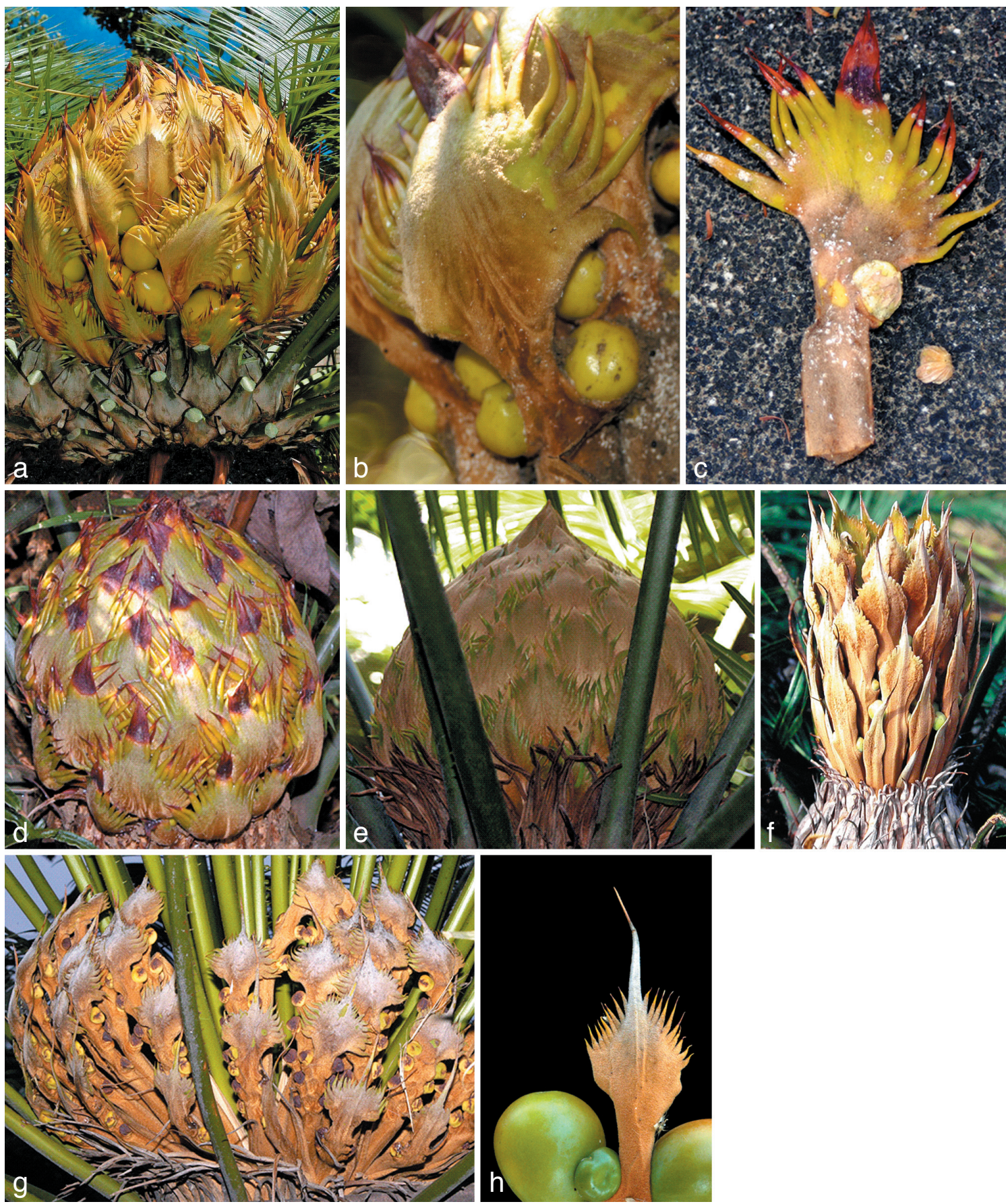

Plate 2 Megasporophylls. a. Cycas wadei Merr.; b-e. C. curranii (J.Schust.) K.D.Hill; f. C. edentata de Laub.; g. C. riuminiana Porte ex Regel; h. C. zambalensis Madulid \& Agoo.

least 5 locations, continuing decline in quality of habitat, small population size: < 10000 individuals (as per actual count of 20-25 individuals per $400 \mathrm{~km}^{2}$ ). Its category in the Philippines is Endangered.

Descriptive notes - Cycas riuminiana can be readily distinguished by the sterile part of the megasporophyll being broader than long.

\section{Cycas silvestris K.D.Hill - Plate 3}

Cycas silvestris K.D.Hill (1992) 181, t. 1; de Laub. \& Adema (1998) 372. Cycas rumphii auct. non Miq.; Merr. (1918) 52; (1923) 1; Quisumb. (1951) 74; Pancho (1983) 38, f. 3.

Cycas circinalis auct. non L.: Blanco (1837) 745; Foxw. (1911) 151, pl. 26; Merr. (1912) 65; Amoroso (1986) 182, f. 5, 7-9, 27-30.

Distribution - Vietnam to Northern Australia; throughout the Philippines.
Habitat - Lowland inland, occasionally coastal forests. Conservation status - Cycas silvestris is a widespread forest species. Its current conservation status can not be ascertained for lack of available field data. Its category is Data Deficient.

Descriptive notes - This species can be distinguished by its megasporophylls having teeth which are almost of the same length.

Cycas wadei Merr. - Plate 1d, 2a, 3

Cycas wadei Merr. (1936) 234, pl. 1-4; Zamora \& Co (1979) 222, f. 4; Amoroso (1986) 183, f. 1, 20-22, 31-34; de Laub. \& Adema (1998) 385.

Cycas circinalis subsp. riuminiana var. curranii forma graminea J.Schust. (1932) 69.

Cycas sp. Foxw. (1911) 152, pl. 27; Merr. (1923) 2.

Distribution - Philippines: restricted to Culion Island. 


\section{0}
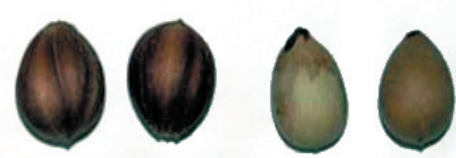

$2 \mathrm{~cm}$
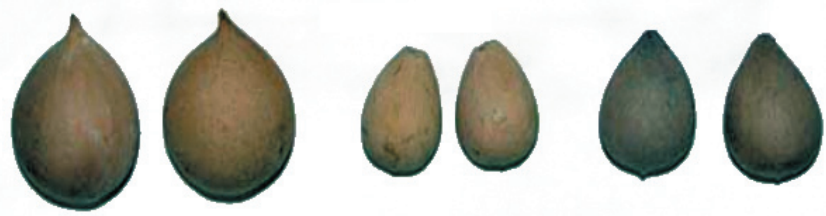

Plate 3 Seeds showing woody sarcotesta. Upper row from left: Cycas curranii (J.Schust.) K.D.Hill, C. wadei Merr., C. silvestris K.D.Hill. Lower row from left: C. edentata de Laub., C. zambalensis Madulid \& Agoo, C. riuminiana Porte ex Regel.

Habitat - Open grasslands.

Conservation status - The species is limited to the grasslands of Culion Island, Palawan province. It is threatened by fire which are set off seasonally to regenerate grass for cattle. The area is also threatened by expanding human settlement. The (maximum) extent of occurrence is $650 \mathrm{~km}^{2}$, with only one location, continuing decline in quality of habitat, very restricted area of occupancy. Based on these criteria, its category is Critically Endangered.

Descriptive notes - This species has megasporophylls with the sterile part broad and fan-like similar to C. curranii. Like C. curranii, the sarcotesta has longitudinal ribs but these are not pronounced and fewer in number.

\section{Cycas zambalensis Madulid \& Agoo - Plate 1c, 2h, 3}

Cycas zambalensis Madulid \& Agoo (2005) 519, f. 1.

Distribution - Philippines: Luzon (Zambales): San Antonio, Kawag, Botolan.

Habitat - Open grasslands; ultrabasic hills.

Conservation status - The species is limited to the ultramafic hills of Zambales, particularly in San Antonio, Kawag, and Botolan. Seedlings and even mature trees are collected by the local people for the horticultural market. The grasslands are burned to regenerate grass for cattle and for hunting purposes. Some of these areas are threatened by mining operation. Some areas are also being developed as resorts and other land uses. The (maximum) extent of occurrence is (less than) $116 \mathrm{~km}^{2}$, with only two adjoining locations, continuing decline in quality of habitat, and very restricted area of occupancy. Based on these criteria, its category is Critically Endangered.

Descriptive notes - This is the only Philippine species found confined to open ultrabasic hills. It has tomentose rachis and petioles. The seeds are smooth and slightly flat.

\section{INTRODUCED SPECIES}

\section{Cycas revoluta Thunb.}

Cycas revoluta Thunb. (1783) 40; Merr. (1912) 65; (1923) 1; Quisumb. (1951) 74; Zamora \& Co (1979) 221, f. 3; Pancho (1983) 38; Amoroso (1986) 183, f. 3, 35-38; de Laub. \& Adema (1998) 384.

Habitat - In gardens.

Conservation status - Cycas revoluta is an introduced species and is widely distributed in the country. It is grown mainly as an ornamental in landscaped gardens. The leaves are also used as decorations and a symbol during the Lenten season.
Descriptive notes - Cycas revoluta is similar to C. zambalensis in leaf structure and in having tomentose petiole and rachis, but can be distinguished by its strongly revolute pinnules.

\section{REFERENCES}

Amoroso VB. 1986. Morphological study of the sporophylls of Philippine Cycas. Philippine Journal of Science 115, 3: 177-197.

Blanco M. 1837. Flora de Filipinas según el sistema sexual de Linneo. Lopez, Manila, Philippines.

Brown W, Kienholz R. 1925. Cycas chamberlainii, a new species. Philippine Journal of Science, section C, botany 2, 1: 47-51.

De Laubenfels DJ, Adema F. 1998. A taxonomic revision of the genera Cycas and Epicycas gen. nov. (Cycadaceae). Blumea 43: 351-400.

Foxworthy FW. 1911. Philippine gymnosperms. Philippine Journal of Science, section C, botany 6: 151-172.

Hill KD. 1992. A preliminary account of Cycas (Cycadaceae) in Queensland. Telopea 5: 177-206.

Hill KD. 1995. Cycas curranii (J.Schust.) K.D. Hill. In: Vorster P (ed), Proceedings of the Third International Conference on Cycad Biology: 150.

Hill KD. 1998-2004. The Cycad Pages. http://plantnet.rbgsyd.nsw.gov. au/PlantNet/cycad/index.html. Last accessed 2008.

Hill KD. 1999. Cycas falcata (Cycadaceae): a new species from Sulawesi, Indonesia. Kew Bulletin 54, 1: 209.

Hill KD, Lindstrom A. 2008. The genus Cycas in the Philippines. Telopea 12, 1: 128.

Madulid DA, Agoo EMG. 2005. A new species of Cycas (Cycadaceae) from the Philippines. Blumea 50: 519-522.

Merrill ED. 1912. A Flora of Manila. Bureau of Printing, Manila

Merrill ED. 1918. Species Blancoanae: a critical revision of the Philippine species of plants described by Blanco and Llanos. Bureau of Science Publication 12: 1-423.

Merrill ED. 1923. Cycadaceae. An enumeration of Philippine flowering plants 1: 1-2. Bureau of Printing, Manila.

Merrill ED. 1936. A new Philippine species of Cycas. Philippine Journal of Science 60, 3: 233-242.

Pancho JV. 1983. Vascular Flora of Mt Makiling and vicinity (Luzon: Philippines). Part I. Kalikasan, The Philippine Journal of Biology Supplement Number 1: 38-41, f. 3. Kalikasan Press, Manila.

Quisumbing E. 1951 Medicinal plants of the Philippines. Department of Agriculture and Natural Resources Technical Bulletin 16: 74-76. Manila.

Regel E. 1863. Cycas riuminiana Porte. Gartenflora 12: 16-17.

Schuster J. 1932. Cycadaceae. In: Engler A (ed), Das Pflanzenreich 99: 69. Thunberg CP. 1783. Nova genera plantarum 3. Nova Acta Regiae Societatis Scientiarum Upsaliensis 40.

Zamora P, Co L. 1979. Guide to Philippine flora and fauna: Gymnosperms. Diliman, Q.C., Philippines.

\section{IDENTIFICATION LIST}

The numbers after the collector numbers refer to the following species:

$$
\begin{aligned}
& 1=\text { C. curranii (J.Schust.) K.D. Hill } \\
& 2=\text { C. edentata de Laub. } \\
& 3=\text { C. riuminiana Porte ex Regel } \\
& 4=\text { C. silvestris K.D. Hill } \\
& 5=\text { C. wadei Merr. } \\
& 6=\text { C. zambalensis Madulid \& Agoo } \\
& 7=\text { C. revoluta Thunb. }
\end{aligned}
$$

Brown \& Kienholz BS 42539: 3.

Claustro PNH 116502: 4 - Conklin PNH 37914: 2.

Flores et al. 1001: 3 - Fox 176: 4.

Jolito 1005: 6.

Kondo 32862: 2 - Kondo \& Edaño 36768: 4; 38877: 2.

Linis 001: 3; 002: 3; 003: 3; 004: 3; 005: 1; 007: 6; 008: 6.

Madulid 7232: 3 - Madulid \& Agoo PNH 173358: 6 - Madulid \& Sebastian 9000: 5 - Madulid et al. 1350: 2; 1358: 2; 1367:2; 9062: 3 - Mendoza PNH 37074: 2.

Quisumbing et al. PNH 79440: 4.

Taleon PNH 33848: 2. 